\title{
Potential Natural Dyes Food from the Powder of Prickly Pear Fruit Peels (Opuntia spp.) Growing in the Mediterranean Basin under Climate Stress
}

\author{
Mohammed Bourhia $\left(\mathbb{D},{ }^{1}\right.$ Hamza Elmahdaoui ${ }^{D},{ }^{2}$ Samir Iben Moussa, ${ }^{1}$ Riaz Ullah (D), ${ }^{3}$ \\ and Ahmed Bari ${ }^{4}$ \\ ${ }^{1}$ Laboratory of Chemistry, Biochemistry, Nutrition, and Environment, Faculty of Medicine and Pharmacy, University Hassan II, \\ Casablanca, Morocco \\ ${ }^{2}$ Laboratory of Food Technology and Quality, Regional Center for Agricultural Research in Marrakesh, \\ National Institute for Agricultural Research, INRA, Marrakesh, Morocco \\ ${ }^{3}$ Medicinal Aromatic and Poisonous Plants Research Center, College of Pharmacy, King Saud University, P.O. Box 2457, \\ Riyadh 11451, Saudi Arabia \\ ${ }^{4}$ Central Laboratory, College of Pharmacy, King Saud University, P.O. Box 2457, Riyadh 11451, Saudi Arabia
}

Correspondence should be addressed to Mohammed Bourhia; bourhiamohammed@gmail.com and Hamza Elmahdaoui; hamza.elmahdaoui@edu.uca.ac.ma

Received 20 November 2019; Revised 30 December 2019; Accepted 9 January 2020; Published 26 February 2020

Academic Editor: Beom Soo Kim

Copyright ( $) 2020$ Mohammed Bourhia et al. This is an open access article distributed under the Creative Commons Attribution License, which permits unrestricted use, distribution, and reproduction in any medium, provided the original work is properly cited.

Background. Barbary fig (Opuntia spp), called prickly pear, is a cultivated species belonging to family Cactaceae. It produces fruits one time per year during a short season. It is largely spreading in the Mediterranean countries. The aim of the study was to investigate the physicochemical and biochemical analysis of powder of prickly pear fruit peels of three Moroccan varieties (Aakria, Derbana, and Mles). Material and Methods. Both physicochemical analysis (humidity, water activity, Brix, ash content, $\mathrm{pH}$, and total titratable acidity) and biochemical analysis (total carotenoid content, betalain content, total polyphenolic content, and ascorbic acid content) were effectuated according to protocols reported within the present research work. Results. Regarding the physiochemical analysis, the humidity of powder of prickly pear fruit peels ranged from $10.173 \pm 0.002$ to $15.27 \pm 0.02 \%$. The water activity (aw) ranged from $0.17 \pm 0.002$ to $0.336 \pm 0.002$. The values of Brix ranged from $68.67 \pm 0.33$ to $74.22 \pm 0.51^{\circ} \mathrm{Bx}$. $\mathrm{pH}$ values ranged from $5.41 \pm 0.01$ to $5.62 \pm 0.01$. The total titratable acidity values ranged from $0.644 \pm 0.014$ to $0.76 \pm 0.007 \mathrm{~g}$ citric acid/100 g DM (dry matter). The ash content ranged from $1.02 \pm 0.02$ to $11.41 \pm 0.03 \mathrm{~g} / 100 \mathrm{~g}$ DM. Regarding the biochemical analysis, the total carotenoid content ranged from $5.14 \pm 0.10$ to $9.79 \pm 0.06 \mathrm{mg} / \mathrm{g}$ of FM (Fresh matter). The total betalain content ranged from $2 \pm 0.69$ to $37.66 \pm 2.65 \mathrm{mg} / 100 \mathrm{~g}$ of DM. The total polyphenolic content ranged from $1739.92 \pm 13.69$ to $2409.66 \pm 43.65 \mathrm{mg}$ gallic acid equivalent (GAE)/100 g of DM. The ascorbic content values ranged from $186.78 \pm 13.23$ to $294.04 \pm 5.81 \mathrm{mg} / 100 \mathrm{~g}$ of DM. Conclusion. The results showed an interesting richness of the investigated powder in pigments (betacyanins, indicaxanthins, and carotenoids) and nutritional compounds including sugar, proteins, and vitamins that make this powder interesting for being used as a dye in food.

\section{Introduction}

Humans have always used plants as a source of food. From the earliest times, plants constitute a food reservoir of both animals and humans. Plants have been largely used in medicine to cure disease and provide drugs. Plants give people on earth pleasure through gardening [1]. People on the earth still linked to plants for food whether directly or as feed for animals breeding. Agriculture plays a key role in food crop production and the civilizations of the world. Nowadays about 7,000 species of plants are used for food though most of today's only 30 species are used intensively for food. Nonfood products such as essential oils, natural dyes, and pigments are also derived from plants [2]. 
Prickly pear (Opuntia spp.) called "Barbary fig" is one of the most important perennial crop species, which has the ability to adapt to stress even at low soil potential. It is becoming more important for social and economic development. Therefore, Barbary fig has drawn attention for being valorized and listed as promising projects for the development of rural areas. The prickly pear is a plant native to Mexico areas. It was introduced in the 16th century to the Mediterranean basin such as North of Africa by Spaniards, where it was naturalized $[3,4]$. Nowadays prickly pear is found in a range of climates ranging from the Mediterranean to tropical [5]. Barbary fig has widely grown in Moroccan rural landscape. Its geographical distribution is quite extensive; it is extending from the coastal regions of Sidi Ifni to Tangier city. In the Tiznit land, the crops of Barbary fig have occupied a total area of 17,600 ha. $65 \%$ of which are in the region of Sidi Ifni and Aït Baâmrane. In the study area, more than 1500 known species of prickly pear are springing from genera Opuntia [6].

Barbary fig fruit possesses interesting chemical compounds, which can provide it with good nutritional value. High genetic variability is preserved in the Moroccan prickly pear. Several varieties have been distinguished by the flowering period (early or late), the color of the flower, the color of fruit and pulp, the shape of fruits (ovoid, round and oblong), the organoleptic criteria of fruits, and the antioxidant power [7]. The fruits of the prickly pears containing betalain pigments that provide them with good potential for use as natural dyes or cosmetics. These fruits contain betacyanins, in addition to betaxanthins $[8,9]$.

The present study aims to valorize the powder of dried peels of three prickly pear varieties (Aakria variety, Derbana variety, and Mles variety) growing in dry Moroccan zones in terms of quality and stability with different humidity levels $(15 \%$ and $10 \%)$.

\section{Material and Methods}

2.1. Study Area. The investigated varieties of Barbary fig were collected from Rhamna land, an area located at the central west of Maghreb (Morocco), about $100 \mathrm{~km}$ Northwest of Marrakech touristic city (Figure 1).

2.1.1. Regional Climatic Conditions. Rhamna land is described by arid Mediterranean climates over the year (cold winter and dry summer) according to earlier reported data (Emberger's Pluviothermic Quotient: $Q^{2}=20.6$ ). Insufficient and irregular annual rainfall extends throughout the study area (Xeric Climate). The annual mean of precipitation is about $130 \mathrm{~mm}$ (methodological station of Ben Guerir, 2017). According to Gaussen and Bagnouls diagram, Rhamna land classified as dry area (Figure 2).

2.2. Plant Material. The investigated varieties of Barbary fig were collected from Rhamna land at the end of maturity in August of 2015. The studied species were identified by a botanist. The fruits were peeled in order to obtain the requested peels; the fresh peels were left at room temperature

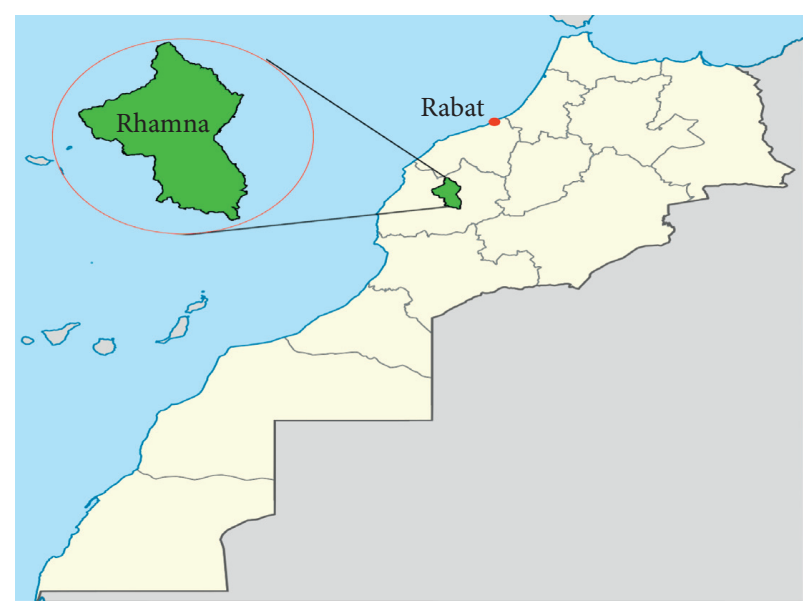

FIgURE 1: Geographical position of the study area (region of Rhamna, Morocco).

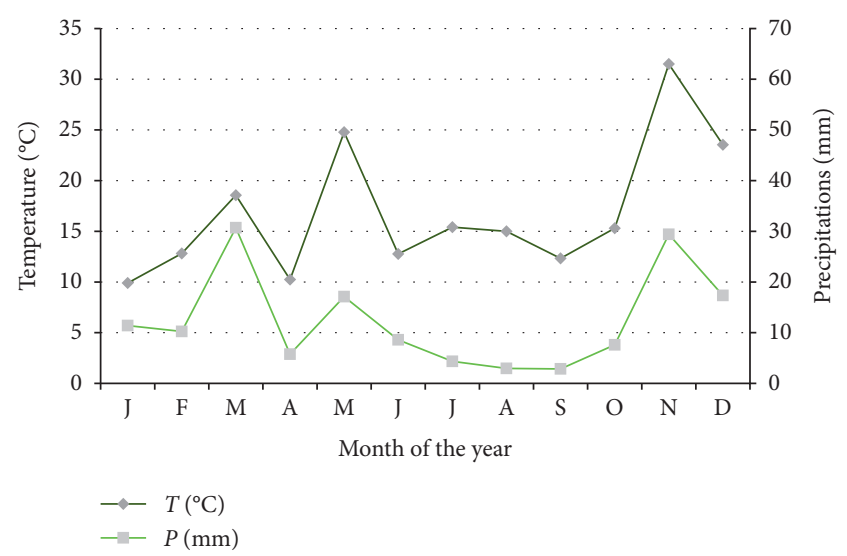

Figure 2: Diagram of Gaussen and Bagnouls of the study area (2015-2016).

for the drying process. The dried peels were ground into powder. The studied varieties are presented in Figures 3-5.

2.2.1. Preparation of Powder of Prickly Pear Fruit Peels. Two types of powders were prepared from the fruit peels of the investigated varieties in order to evaluate the stability and the quality of the present product:

(i) A powder at moisture content $15 \%$

(ii) A powder at moisture content $10 \%$

The choice of these moisture levels was not randomly but was based on previous work, in which it was reported that the peels of Opuntia spp. got dried up at moisture levels ranged from $10 \%$ to $18 \%[7,9]$.

The peels were placed into an oven at $60^{\circ} \mathrm{C}$ for drying. To reach the fixed moisture levels (15\% and 10\%), preliminary tests were carried out by drying the peels and determining the reduction of humidity content as a function of time of drying. Once the desired humidity level was reached, the drying was stopped and the drying time was determined. The dried peels were then crushed and stored in hermetically sealed glass jars away from light. 


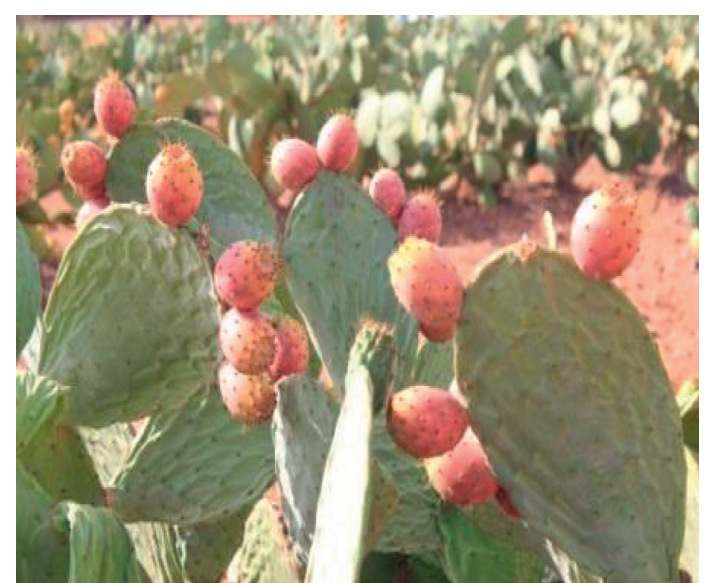

(a)

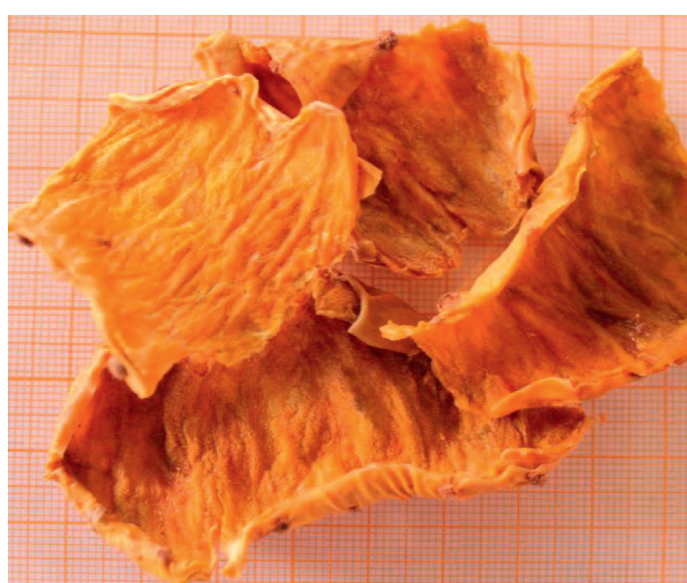

(b)

Figure 3: Aakria variety (Opuntia ficus-indica): (a) Aakria Plant. (b) Aakria Peels.

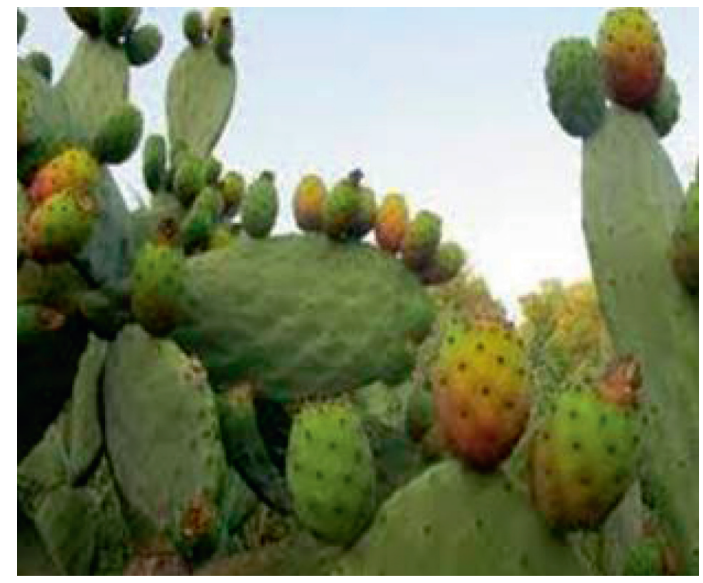

(a)

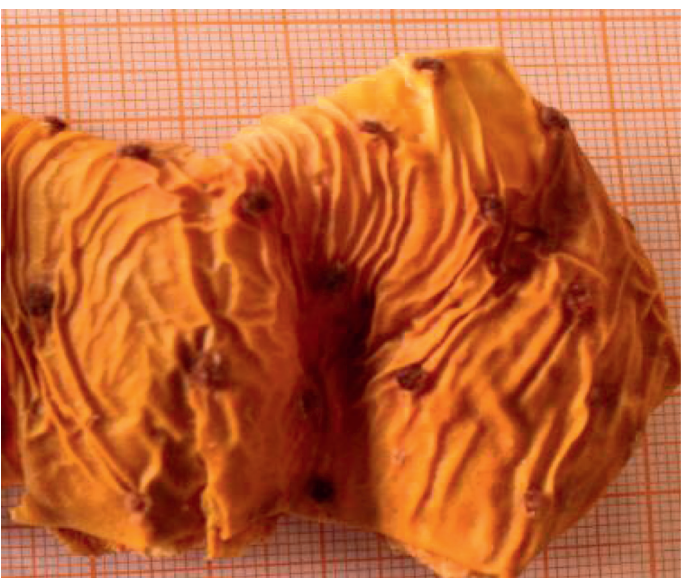

(b)

Figure 4: Derbana variety (Opuntia megacantha): (a) Derbana Plant. (b) Aakria peels.

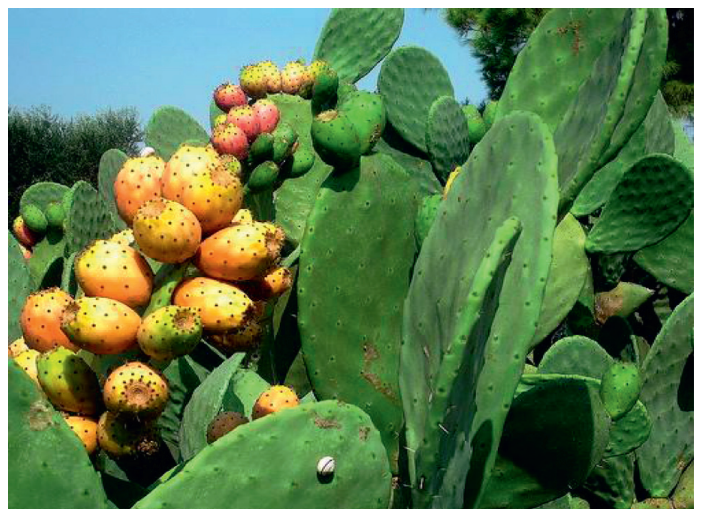

(a)

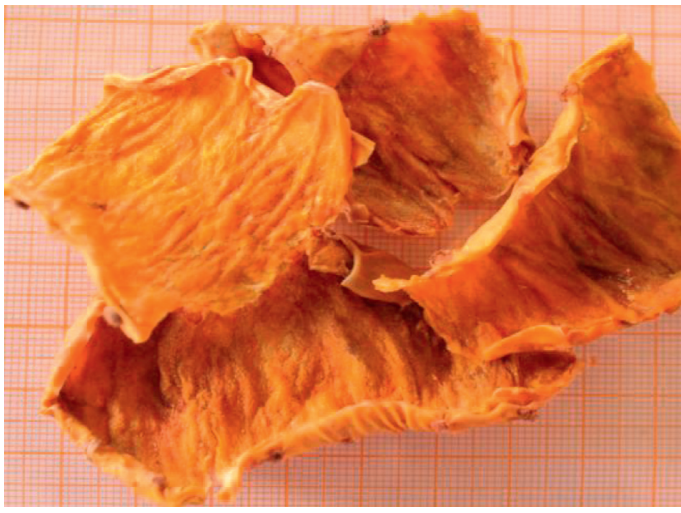

(b)

Figure 5: Mles variety (Opuntia ficus-indica): (a) Mles Plant. (b) Mles Peels. 


\subsection{Physicochemical Analysis of Powder of Prickly Pear Fruit Peels}

2.3.1. Humidity Determination. $5 \mathrm{~g}$ of powder was placed in a vacuum oven at $105^{\circ} \mathrm{C}$ for 48 hours. At the end of the drying, the obtained final weight of the sample was measured again. Three repetitions were performed according to a previously reported method [10].

The humidity \% was determined as follows:

$$
\text { Humidity } \%=\left(\frac{\mathrm{Iw}-\mathrm{Fw}}{\mathrm{Iw}}\right) * 100 \text {, }
$$

where Iw is the weight of the test portion measured before steaming (g) and Fw is the weight of the test portion measured after steaming $(\mathrm{g})$.

2.3.2. Water Activity Determination. $5 \mathrm{~g}$ of powder was placed in an aw-meter at a temperature of $25^{\circ} \mathrm{C}$ for 2 hours deemed sufficient to reach the balance between the sample and the surrounding atmosphere. Then aw was read using aw-meter. Three repetitions were carried out.

2.3.3. $\mathrm{pH}$ Determination. The $\mathrm{pH}$ of powder of prickly pear fruit peels was determined using a $\mathrm{pH}$ meter. A solution was prepared with distilled water then neutralized at a ratio of 1 : 6 (the studied powder: volume of distilled water).

2.3.4. Determination of Titratable Acidity. This parameter was determined as follows: $25 \mathrm{~g}$ of powder supplemented with distilled water and boiled for $30 \mathrm{~min}$. The obtained solution was filtered, then titrated with $\mathrm{NaOH}(0.1 \mathrm{~N})$ until $\mathrm{pH}=8.1$.

The results were reported in $\mu$ g citric acid equivalent per g of DM:

$$
\text { Total titratable acidity }(\mathrm{g} \text { c.a } / 100 \mathrm{~g})=\frac{((\mathrm{VNaOH} \text { added } * \mathrm{NNaOH} * 0.07) / \mathrm{Vs})}{100} * \mathrm{Sw},
$$

where $\mathrm{VNaOH}$ is the $\mathrm{NaOH}$ volume (in $\mathrm{ml}$ ); $\mathrm{NNaOH}$ is the $\mathrm{NaOH}$ normality; $\mathrm{Vs}$ is the sample of titrated volume (in $\mathrm{ml}$ ); c.a: citric acid; 0.07 is the coefficient of citric acid; and Sw is the weight of sample.

2.3.5. Brix Determination. Regarding the analysis of dried peels, the test portion was $1 \mathrm{~g}$ solubilized in $10 \mathrm{ml}$ of distilled water at a ratio of $1: 10$ (used powder: used distilled water). The assay was performed in triplicate. The results were reported in degree Brix (Bx).

2.3.6. Determination of Ash Content. $2 \mathrm{~g}$ of powder of prickly pear fruit peels was placed for incineration at a temperature of $500^{\circ} \mathrm{C}$ for 7 hours; three repetitions were carried out. The ash content was reported as a percentage relative to dry matter (DM):

$$
\text { Ashes in } \mathrm{g} / 100 \mathrm{gDM}=\left[\frac{(\mathrm{Iw}-\mathrm{Fw}) * 100}{100-H}\right] * 100,
$$

where Iw is the measured weight of the test sample before incineration $(\mathrm{g})$; $\mathrm{Fw}$ is the measured weight of the test sample after incineration (g); and $H$ is the humidity (\%).

2.3.7. Colour Determination. In the current work, the color was determined for powders at $15 \%$ and $10 \%$ of humidity content. A colorimeter was used for measuring the parameters of the color or space $\operatorname{Lab}\left(L^{*}, a^{*}\right.$ and $\left.b^{*}\right)$. $L^{*}$ value ranged from 0 (black) to 100 (white), $a^{*}$ value ranged from -100 (green) to +100 (red), and the value of $b^{*}$ ranged from -100 (blue) to +100 (yellow). When the values of $L^{*}, a^{*}$ and $b^{*}$ increase, the color is more chromatic, by the time the value of neutral colors such as white, gray, and black tends to be zero.
Chroma was calculated as follows:

$$
C=\left[a^{* 2}+b^{* 2}\right]^{0.5} \text {. }
$$

where $C^{*}$ is the chroma (represents the purity of the color); $a^{*}$ represents a range of 200 levels on the red axis $(+100) \longrightarrow$ green $(-100)$ through gray $(0)$; and $b^{*}$ represents a range of 200 levels on the yellow axis $(+100) \longrightarrow$ blue $(-100)$ through gray $(0)$.

\subsection{Biochemical Analysis of Powder of Prickly Pear Fruit Peels}

2.4.1. Total Carotenoid Content Determination. $1 \mathrm{~g}$ of powder of prickly pear fruit peels was mixed with $10 \mathrm{ml}$ of solvents (50\% hexane, $25 \%$ acetone, and 25\% ethanol). The mixture was vortexed for $1 \mathrm{~min}$ and centrifuged at $6500 \mathrm{~g}$ for $5 \mathrm{~min}$ at a temperature of $5^{\circ} \mathrm{C}$. The supernatant containing the pigments was recovered again then adjusted with hexane. OD (Optic density) was read at $450 \mathrm{~nm}$ according to earlier described methods [11]. The assay was performed in triplicate:

Total carotenoid content $(\mu \mathrm{g}$ eq $\beta-$ carotene $/ \mathrm{g})=\frac{A_{450} * V * 106}{2500 * 100 * \mathrm{Sw}}$,

where $A_{450}$ is the read absorbance at $450 \mathrm{~nm}$; $V$ is the analysed volume of the sample $(1 \mathrm{ml})$; and SW is the weight of Sample $(\mathrm{g})$.

2.4.2. Betalain Content Determination. $0.5 \mathrm{~g}$ of powder of prickly pear fruit peels was mixed with methanol $80 \%(\mathrm{v} / \mathrm{v})$ for one minute and centrifuged at $4000 \mathrm{rpm}$ for 20 minutes. The recovered supernatant was read by spectrophotometer at $480 \mathrm{~nm}$ and $538 \mathrm{~nm}$ for the determination of both, 
betaxanthins and betacyanins, respectively, according to earlier data [11]. Betalain content was determined as follows:

$$
\text { Betalain content }(\mu \mathrm{g} / 100 \mathrm{~g})=\left(\frac{(A * \mathrm{Df} * \mathrm{Mw} * 1000 /(\xi * \mathrm{Wt}))}{\mathrm{Sw} * 100}\right) \text {, }
$$

where $A$ is the absorbance; $\mathrm{Df}$ is the dilution factor; $\mathrm{Wt}$ is the width of the tank $(1 \mathrm{~cm}) ; \xi$ is the molar extinction coefficient $(\mathrm{L} / \mathrm{mol} * \mathrm{~cm})$; $\mathrm{Mw}$ is the molecular weight $(\mathrm{g} / \mathrm{mol}) ; \lambda$ is the wavelength $(\mathrm{nm})$; and $\mathrm{Sw}$ is the sample weight.

\subsubsection{Total Polyphenol and Ascorbic Acid Content Determination}

(1) Extraction. Powder of Barbary fig fruit peels was placed for extraction with $10 \mathrm{ml}$ of acetone (70\%) and (80\%). The mixture was centrifuged at $5000 \mathrm{rpm}$ for $30 \mathrm{~min}$. The extract obtained was used for dosing the total polyphenol and ascorbic acid content.

2.4.4. Total Polyphenols Determination. Briefly, $25 \mu \mathrm{l}$ of powder of prickly pear peels extract was added to $0.475 \mathrm{ml}$ of methanol and $2.5 \mathrm{ml}$ of Folin-Ciocalteu reagent (10\%). After 2 minutes, $2 \mathrm{ml}$ of sodium carbonate (at $75 \mathrm{~g} / \mathrm{l}$ ) was added. The mixture was placed under incubation at $50^{\circ} \mathrm{C}$ for 15 minutes and then cooled rapidly. The absorbance was read at $760 \mathrm{~nm}$.

The findings were reported in $\mathrm{mg}$ gallic acid equivalent (EAG)/100 g of DM through a standard curve. The assay was performed in triplicate.

2.4.5. Ascorbic Acid Content. $500 \mu \mathrm{l}$ of extract prepared from powder of prickly pear fruit peels was added to $3.5 \mathrm{ml}$ of distilled water then mixed. $2 \mathrm{ml}$ of the current mixture was deposited on an OASIS cartridge embedded with $3 \mathrm{ml}$ of $\mathrm{MeOH}+2 * 3 \mathrm{ml}$ of distilled water. $0.5 \mathrm{ml}$ of the obtained solution was measured. The findings were reported in $\mathrm{mg} /$ $100 \mathrm{~g}$ of DM. The current assay was repeated in triplicate.

2.5. Statistical Analysis. The results were reported as the average \pm standard deviation. Analysis of variance was performed using one-way ANOVA. For performing multiple comparisons between means, the Student-Newman-Keuls method was adopted. A significant difference was taking into account at $p$ less than 0.05 .

\section{Results and Discussion}

\subsection{Physicochemical Analysis of Powder of Prickly Pear Fruit Peels}

3.1.1. Colour of Powder of Dried Peels. Colour is a quality index that plays an important role in the commercial value of food products. Variation of color is closely related to the progression of fruit ripening and other factors that depend on technological treatments [12].
Powder color of the studied peels was red-violet for Aakria variety and yellow-orange for Derbana and Mles varieties (Figure 6). The color parameters $\left(L^{*}, a^{*}, b^{*}\right.$ and chroma $C^{*}$ ) of powders of the current varieties with two moisture contents 15 and $10 \%$ are presented in Table 1.

Analysis of variance showed that the clarity $\left(L^{*}\right)$ differed significantly between powders of Aakria and Derbana varieties regarding the two moisture levels (15 and 10\%) $(p<0.01)$. The luminosity of color decreased due to peels drying (Table 1). The reduction in luminosity was reported in the order of $12.7 \%, 7.9 \%$ and $1.8 \%$ for Aakria, Derbana, and Mles respectively.

The values $a^{*}$ represent that the range of color green/red was positive that indicates an appearance of red color. These were very high in the powder of Aakria variety compared to other varieties (Derbana and Mles). These results could explain the richness of this variety in red pigments of betacyanin. The monitoring of the current parameter evolution as a function of peels drying showed a significant decrease in the order of $8.29 \%, 3.49 \%$, and $5.76 \%$, respectively, concerning Aakria variety, Derbana variety, and Mles $(p<0.05)$. The highest decrease was recorded in peels of Aakria; this could be explained by the degradation of betalain under drying effect.

The values $b^{*}$ represent that the range of yellow/blue color was positive regarding the studied powder that indicates an appearance of yellow color. When moving from a humidity level of 15 to $10 \%$, a significant decrease of $0.57 \%, 2.13 \%$, and $5.95 \%$ was registered in powders of peels prepared from Aakria, Derbana, and Mles, respectively $(p<0.05)$. This decrease could be due to the degradation of yellow pigments (indicaxanthins) under the drying effect.

The decrease of parameters values $a^{*}$ and $b^{*}$ did not induce a significant reduction of chroma $C^{*}$ values of the studied powders at 15 and $10 \%$ humidity level. The values of chroma color $40.84 \pm 1.12$ and $40.89 \pm 1.45$ obtained for yellow-orange varieties (Derbana and Mles, respectively) were higher than those reported in earlier data regarding fresh peels of prickly pear growing in the South of Morocco (19.12 and 18.27) [13]. The remarkable difference could be due to the richness of the studied peels in pigments (betalains and carotenoids). The present results were in accordance with previous data report on color of dried peels of another variety of Barbary fig fruit 27.56 [14].

The current results showed that the reduction of moisture content from 15 to $10 \%$ influenced the color of fruit peels by decreasing of parameter values of $a^{*}$ and $b^{*}$. This decrease was resulted due to drying of peels and could be explained by involving of browning reactions.

3.1.2. Humidity. The values of humidity content of dried peels at two levels $10 \%$ and $15 \%$ ranged from $10.173 \pm 0.002$ to $15.27 \pm 0.02 \%$, respectively (Table 2). Concerning humidity content, the powder of all studied varieties at $10 \%$ did not show a significant difference $(p>0.05)$. However, there was a significant difference between varieties powders at $15 \%$ $(p<0.01)$. 


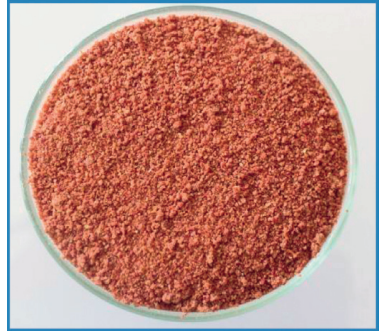

(a)

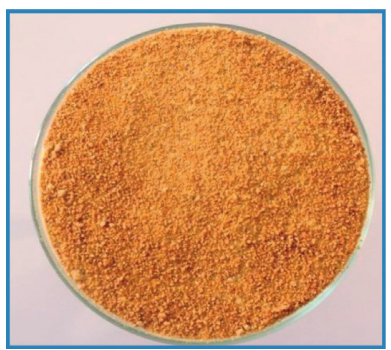

(d)

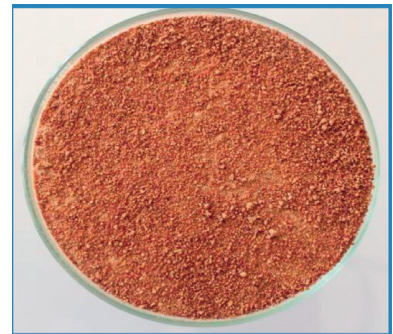

(b)

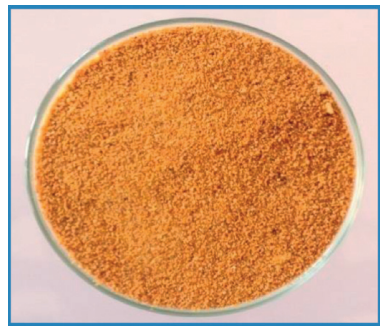

(e)

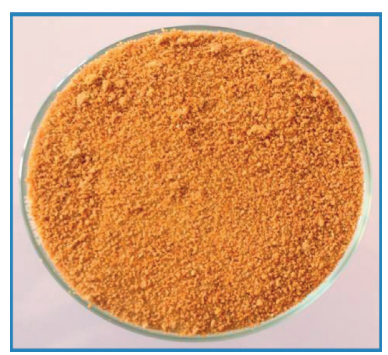

(c)

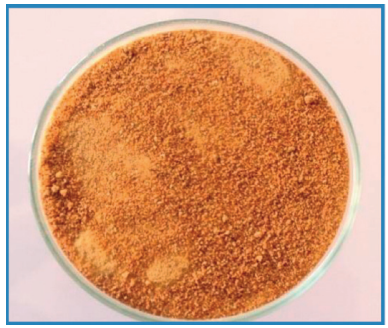

(f)

FIGURE 6: Powders with $15 \%$ and $10 \%$ moisture content of prickly pear fruit peels (Aakria variety, Derbana variety, and Mles variety). (a) Akaria powder with 15\% moisture content. (b) Aakria powder with 10\% moisture content. (c) Derbana powder with 15\% moisture content. (d) Derbana powder with 10\% moisture content. (e) Mles Powder with 15\% moisture content. (f) Mles powder with $10 \%$ moisture content.

TABle 1: Parameters of powder color of prickly pear fruit dried peels (Aakria, Derbana, and Mles) at moisture levels $15 \%$ and $10 \%$.

\begin{tabular}{|c|c|c|c|c|c|c|}
\hline \multirow{2}{*}{$\begin{array}{l}\text { Parameters of } \\
\text { powder color }\end{array}$} & \multicolumn{2}{|c|}{ Aakria } & \multicolumn{2}{|c|}{ Derbana } & \multicolumn{2}{|c|}{ Mles } \\
\hline & $\begin{array}{l}\text { Powder at } 15 \% \\
\text { humidity content }\end{array}$ & $\begin{array}{l}\text { Powder at } 10 \% \\
\text { humidity content }\end{array}$ & $\begin{array}{l}\text { Powder at } 15 \% \\
\text { humidity content }\end{array}$ & $\begin{array}{l}\text { Powder at } 10 \% \\
\text { humidity content }\end{array}$ & $\begin{array}{l}\text { Powder at } 15 \% \\
\text { humidity content }\end{array}$ & $\begin{array}{l}\text { Powder at } 10 \% \\
\text { humidity content }\end{array}$ \\
\hline$L^{*}$ & $43.14 \pm 5.22^{\mathrm{b}}$ & $37.93 \pm 2.92^{\mathrm{a}}$ & $56.57 \pm 2.26^{\mathrm{d}}$ & $51.79 \pm 1.97^{\mathrm{c}}$ & $53.70 \pm 2.02^{\mathrm{c}}$ & $52.08 \pm 3.11^{\mathrm{c}}$ \\
\hline$a^{*}$ & $19.53 \pm 1.36^{\mathrm{d}}$ & $17.91 \pm 1.05^{\mathrm{c}}$ & $11.17 \pm 0.69^{\mathrm{ab}}$ & $10.78 \pm 0.73^{\mathrm{a}}$ & $11.28 \pm 0.17^{\mathrm{b}}$ & $10.63 \pm 1.04^{\mathrm{a}}$ \\
\hline$b^{*}$ & $19.43 \pm 1.74^{\mathrm{b}}$ & $19.32 \pm 2.53^{\mathrm{a}}$ & $39.38 \pm 1.13^{\mathrm{d}}$ & $38.54 \pm 1.50^{\mathrm{cd}}$ & $39.47 \pm 1.33^{\mathrm{d}}$ & $37.26 \pm 1.50^{\mathrm{c}}$ \\
\hline Chroma $\left(C^{*}\right)$ & $27.93 \pm 0.70^{\mathrm{a}}$ & $27.56 \pm 1.68^{\mathrm{a}}$ & $40.84 \pm 1.12^{\mathrm{b}}$ & $40.13 \pm 1.44^{\mathrm{b}}$ & $40.89 \pm 1.45^{\mathrm{b}}$ & $39.43 \pm 0.94^{\mathrm{b}}$ \\
\hline
\end{tabular}

$L^{*}$ represents the luminosity ( $L=0$ for black, 100 for white); $a^{*}$ represents red/green color values; $b^{*}$ represents yellow/blue color values; Colour index: Chroma $C^{*}=[\mathrm{a} * 2+\mathrm{b} * 2]^{0.5}$. The results were reported as average average \pm standard deviation. The reported values with the same letter in the same line did not differ significantly at $p<0.05$.

TAвle 2: Physicochemical analysis of powders of prickly pear fruit peels at moisture levels 15 and 10\% (Aakria, Derbana, and Mles).

\begin{tabular}{|c|c|c|c|c|c|c|}
\hline \multirow[b]{2}{*}{ Criteria } & \multicolumn{2}{|c|}{ Plants } & \multicolumn{2}{|c|}{ Derbana } & \multicolumn{2}{|c|}{ Mles } \\
\hline & $\begin{array}{l}\text { Powder at } 15 \% \\
\text { humidity } \\
\text { content }\end{array}$ & $\begin{array}{l}\text { Powder at } 10 \% \\
\text { humidity content }\end{array}$ & $\begin{array}{l}\text { Powder at } 15 \% \\
\text { humidity content }\end{array}$ & $\begin{array}{l}\text { Powder at } 10 \% \\
\text { humidity content }\end{array}$ & $\begin{array}{l}\text { Powder at } 10 \% \\
\text { humidity content }\end{array}$ & $\begin{array}{l}\text { Powder at } 15 \% \\
\text { humidity content }\end{array}$ \\
\hline Humidity (\%) & $15.27 \pm 0.02^{\mathrm{c}}$ & $10.80 \pm 0.05^{\mathrm{a}}$ & $15.57 \pm 0.02^{\mathrm{d}}$ & $10.71 \pm 0.01^{\mathrm{a}}$ & $15.04 \pm 0.07^{\mathrm{b}}$ & $10.71 \pm 0.01^{\mathrm{a}}$ \\
\hline Water activity & $0.30 \pm 0.001^{\mathrm{d}}$ & $0.187 \pm 0.008^{b}$ & $0.33 \pm 0.002^{\mathrm{e}}$ & $0.176 \pm 0.001^{\mathrm{a}}$ & $0.28 \pm 0.001^{\mathrm{c}}$ & $0.17 \pm 0.002^{\mathrm{a}}$ \\
\hline Brix $\left({ }^{\circ} \mathrm{Bx}\right)$ & $70.67 \pm 0.67^{b}$ & $73.50 \pm 0.33^{\mathrm{d}}$ & $68.67 \pm 0.33^{\mathrm{a}}$ & $72.67 \pm 0.47^{\mathcal{C}}$ & $71.22 \pm 0.19^{b}$ & $74.22 \pm 0.51^{\mathrm{e}}$ \\
\hline $\mathrm{pH}$ & $5.62 \pm 0.01^{c}$ & $5.52 \pm 0.07^{\mathrm{b}}$ & $5.48 \pm 0.01^{\mathrm{b}}$ & $5.41 \pm 0.01^{\mathrm{a}}$ & $5.54 \pm 0.01^{\mathrm{b}}$ & $5.54 \pm 0.01^{\mathrm{b}}$ \\
\hline $\begin{array}{l}\text { Total titratable } \\
\text { acidity (g citric } \\
\text { acid/100 g of FM) }\end{array}$ & $0.64 \pm 0.014^{\mathrm{a}}$ & $0.637 \pm 0.044^{\mathrm{a}}$ & $0.763 \pm 0.007^{\mathrm{c}}$ & $0.693 \pm 0.010^{\mathrm{b}}$ & $0.726 \pm 0.011^{\mathrm{b}}$ & $0.639 \pm 0.008^{\mathrm{a}}$ \\
\hline $\begin{array}{l}\text { Ash content (g/ } \\
100 \mathrm{~g} \text { of } \mathrm{DM})\end{array}$ & $11.41 \pm 0.03^{\mathrm{a}}$ & $11.37 \pm 0.06^{\mathrm{a}}$ & $11.20 \pm 0.01^{\mathrm{a}}$ & $11.24 \pm 0.01^{\mathrm{a}}$ & $11.02 \pm 0.03^{\mathrm{a}}$ & $11.02 \pm 0.02^{\mathrm{a}}$ \\
\hline
\end{tabular}

The results were reported as average \pm standard deviation. Values with the same letter in the same line did not differ significantly at $p<0.05$. 
3.1.3. Water Activity. ANOVA analysis showed a significant difference in water activity between powders of the investigated varieties at $15 \%$ and $10 \%$ moisture content $(p<0.001)$. The lowest value of water activity was recorded in the powder of peels at $10 \%$ moisture content meanwhile the highest value was registered in powder at $15 \%$ humidity (Table 2). The current values of aw that ranged from $0.173 \pm 0.002$ to $0.336 \pm 0.002$ were found lower than those reported in previous literature regarding another variety of Berbay fig, El Beida 0.410 [15]. The low aw values reported in our work can ensure chemical and microbial stability by inhibiting the growth of microorganisms. Therefore the found value increases the aptitude of powder conservation.

3.1.4. Brix. The Brix values of Derbana variety powder at $15 \%$ moisture content and Mles variety powder at $10 \%$ ranged from $68.67 \pm 0.33$ to $74.22 \pm 0.51^{\circ} \mathrm{Bx}$, respectively. A significant difference was recorded between the powders of studied varieties at two moisture levels $(p<0.05)$. However, no significant difference was recorded between the powders of Aakria and Mles varieties at 15\% humidity (Table 2). In the current research, Brix values of powders at $15 \%$ moisture content were lowest than these recorded in powders at $10 \%$ due to the concentration of soluble dry matter in powder with low humidity.

The values of Brix found in the investigated powders of dried peels were higher than those measured in peels of oranges $46.241 \pm 0.015^{\circ} \mathrm{Bx}[16]$.

3.1.5. $\mathrm{pH}$. $\mathrm{pH}$ values of Aakria and Derbana varieties ranged from $5.41 \pm 0.01$ to $5.62 \pm 0.01$, respectively. ANOVA analysis showed a significant difference between the $\mathrm{pH}$ of dried peels at 15 and $10 \%$ humidity content of both Aakria and Derbana varieties (Table 2). Lower values were reported in earlier data $4.5 \pm 0.1$ and $4.4 \pm 0.1$ regarding fresh and dried Opuntia ficus-indica peels, respectively [17].

3.1.6. Titratable Acidity. ANOVA analysis revealed a significant difference between powders of both, Derbana and Mles varieties at two moisture levels $(15$ and $10 \%)(p<0.05)$ (Table 2). The lowest total titratable acidity value $0.644 \pm 0.014 \mathrm{~g}$ citric acid/100 g DM and the highest $0.763 \pm 0.007 \mathrm{~g}$ citric acid/ $100 \mathrm{~g}$ of DM were attributed to powders of Aakria variety at $10 \%$ moisture content and Derbana variety at $15 \%$ moisture content, respectively. The values of the total titratable acidity obtained in the current work were close to previous found data $0.60 \pm 0.10 \mathrm{~g}$ citric acid/100 g DM [17].

3.1.7. Ash Content. Concerning all varieties, ANOVA analysis revealed no significant difference between the ash content of studied powders at two moisture levels (15 and $10 \%)$ (Table 2). The obtained values of ash content ranged from $11.02 \pm 0.02$ to $11.41 \pm 0.03 \mathrm{~g} / 100 \mathrm{~g}$ DM. These values were in agreement with earlier found data about ash content of Opuntia ficus-indica $11.5 \mathrm{~g} / 100 \mathrm{~g}$ DM [16]. The current findings showed that the powders of prickly pear peels possess high levels of mineral matter. On the other hand, the drying of fresh peels did not affect negatively the mineral content. As reported in previous literature, the prickly pear fruit peels can be considered as promising sources of magnesium, calcium, sodium, and potassium [17].

\subsection{Biochemical Analysis of Powder of Prickly Pear Fruit Peels (Aakria, Derbana, and Mles)}

\subsubsection{Pigment Content}

(1) Total Carotenoid. Regarding all investigated varieties in this study, the total carotenoid content in powders ranged from $5.14 \pm 0.10$ to $9.79 \pm 0.06 \mathrm{mg} / 100 \mathrm{~g}$ of DM (Figure 7). ANOVA analysis revealed a high significant difference between the powders at the two moisture levels (15 and 10\%) $(p<0.001)$

The values of total carotenoid reported in the present research work were lower than those previously reported regarding dried peels of Opuntia ficus-indica at $18.5 \%$ humidity content $12.76 \pm 0.20 \mathrm{mg} / 100 \mathrm{~g}$ of DM [17].

We reported that the total carotenoid contained in powders increased for all studied varieties when moving from $15 \%$ to $10 \%$ moisture content. Therefore, the degree of drying influences by the carotenoid content in the studied powders. This increase could be explained by the concentration of carotenoids in powder at low humidity.

(2) Betalains. Betalains values found in the studied powders of all studied varieties ranged from $2 \pm 0.69$ to $37.66 \pm 2.65 \mathrm{mg} / 100 \mathrm{~g}$ of DM. ANOVA analysis showed a highly significant difference between the total betalain content of powders of studied varieties peels regarding both moisture levels 15 and $10 \%(p<0.001)$ (Figure 8).

Dried peels powder of Aakria variety possessed a higher level of betacyanins (red pigments) compared to powders of Derbana and Mles varieties. Meanwhile, the powder of Derbana was richer in indicaxanthins (yellow pigments) than Aakria variety. The values of betalain content registered for powders of Derbana and Mles varieties were similar to those found in peels of yellow-orange [18]. The powder of Opuntia megacantha (Derbana) possesses a higher level in indicaxanthins than betacyanins. The betacyanin content of Aakria variety was close to that found in previous literature concerning dried peels of Opuntia ficus-indica [14].

3.3. Phenolic Content. Regarding phenolic content, there was a highly significant difference between the powders of the three studied varieties at the two moisture levels (15 and 10\%) (Figure 9).

The total polyphenols values found in the studied powders ranged from $1739.92 \pm 13.69$ to $2409.66 \pm 43.65 \mathrm{mg}$ gallic acid equivalent (GAE)/100 g DM. These results were in accordance with published data about total polyphenols of orange dried peels (1968 $\pm 2 \mathrm{mg} \mathrm{GAE} / 100 \mathrm{~g}$ of DM) [16]. We noted that drying induced a significant reduction in the order of $28 \%, 12 \%$, and $8 \%$ in total polyphenols of powders of Aakria, Derbana, and Mles respectively. The total 


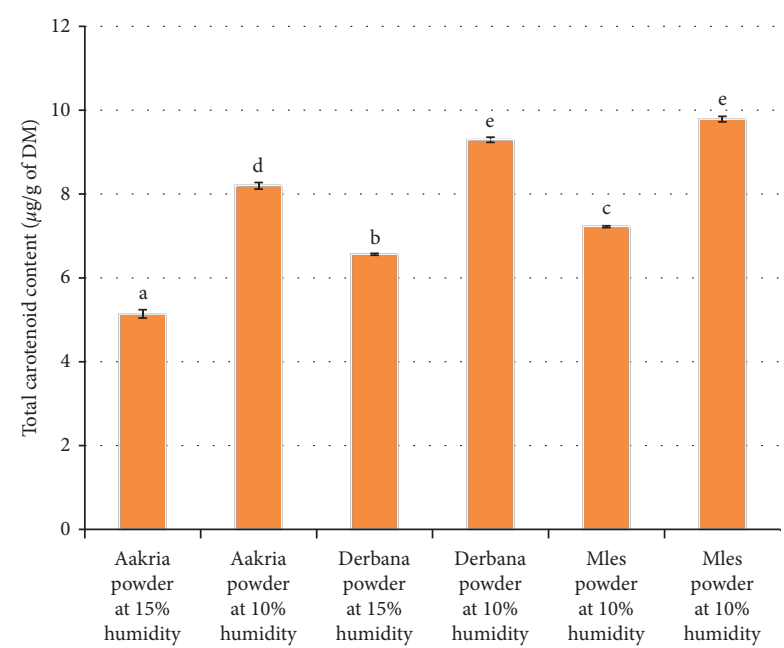

FIgURE 7: Total carotenoid content of powder of prickly pear fruit peels (Aakria variety, Derbana variety, and Mles variety). Means with the same letter do not present a significant difference at $p<0.05$.

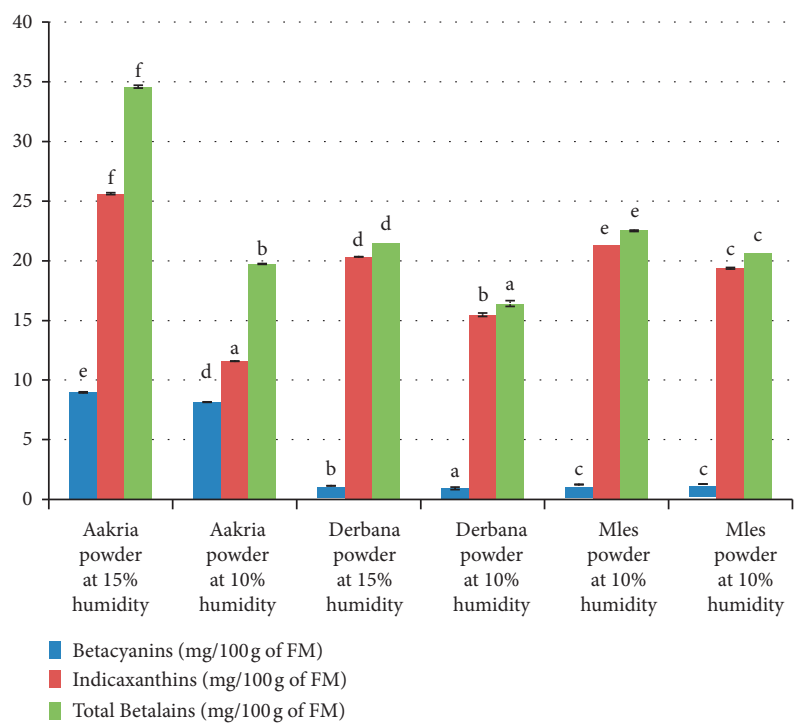

FIgURE 8: Betalain content (betacyanins, indicaxanthin, and total betalains) of powder of prickly pear fruit peels (Aakria variety, Derbana variety, and Mles variety). Means with the same letter do not present a significant difference at $p<0.05$.

polyphenols of Aakria variety were the least stable with increasing drying from 15 to $10 \%$ humidity.

The observed decrease in total polyphenols of the investigated powders due to drying from 15 to $10 \%$ humidity could be explained by the degradation phenomena of these compounds under heating. Our findings were completely in agreement with earlier works [19], in which it was reported that the degradation of polyphenols induced by heat treatment between 50 and $60^{\circ} \mathrm{C}$.

3.4. Ascorbic Acid Content. Regarding all prickly pear varieties, there was a significant difference between ascorbic

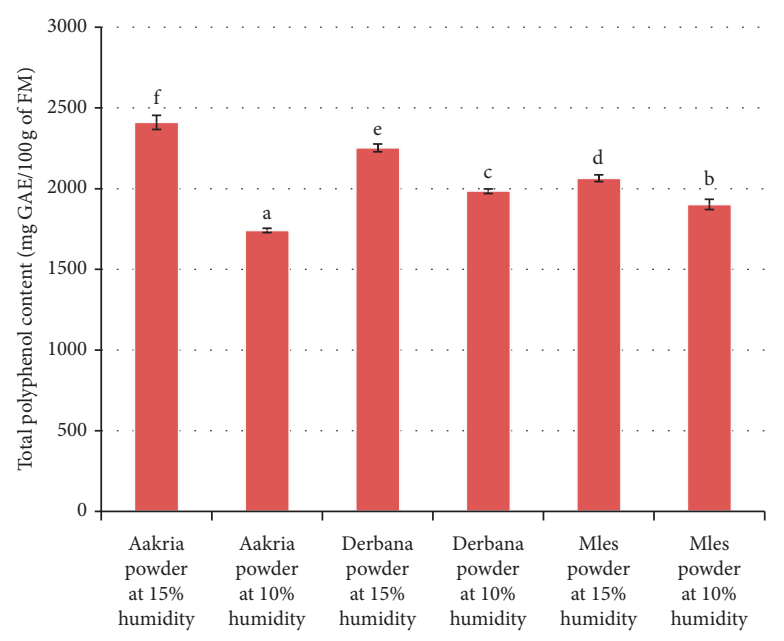

FIgURE 9: Phenolic content of powder of prickly pear fruit peels (Aakria variety, Derbana variety, and Mles variety). Means with different letters present a significant difference at $p<0.05$.

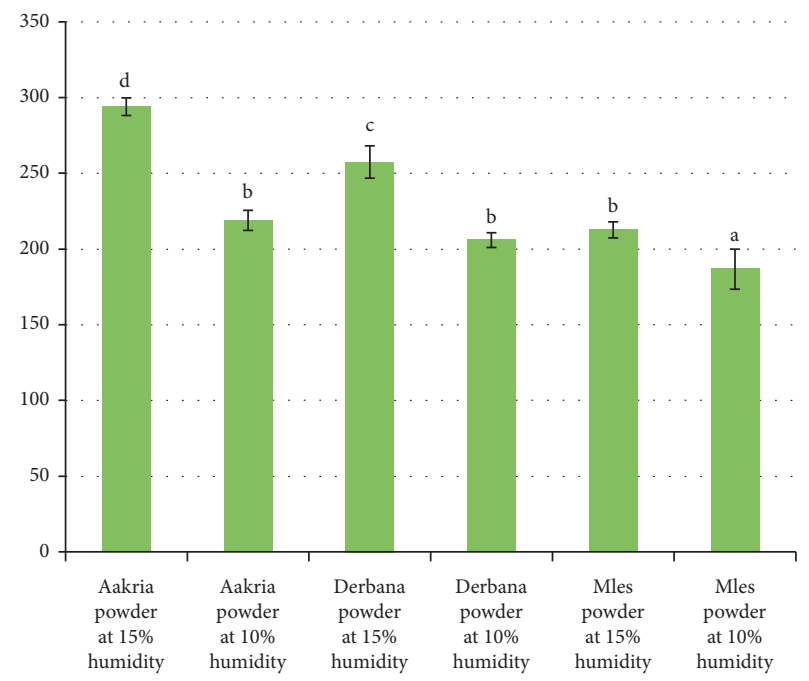

FIgURe 10: Ascorbic acid content of powder of prickly pear fruit peels (Aakria variety, Derbana variety, and Mles variety). Means with the same letter do not present a significant difference at $p<0.05$.

acid contained in powders at the two moisture levels, 15 and $10 \%(p<0.001)$ (Figure 10).

Aakria powder at $15 \%$ humidity and Mles powder at $10 \%$ humidity showed ascorbic acid values $186.78 \pm 13.23$ and $294.04 \pm 5.81 \mathrm{mg} / 100 \mathrm{~g}$ of DM, respectively. These obtained findings were in consent with previous data [17], in which it was reported that the ascorbic acid content revealed in dried peels of Opuntia ficus-indica was at about $288.67 \pm 4.16 \mathrm{mg} /$ $100 \mathrm{~g}$ of DM. The highest values of ascorbic acid content were recorded in dried peels at $15 \%$ humidity compared to those dried at $10 \%$ humidity. The remarkable reductions in powders ascorbic acid content by drying from $15 \%$ to $10 \%$ moisture were in the order of $25 \%, 20 \%$, and $12 \%$ for all varieties Aakria, Derbana, and Mles, respectively. 
We can confirm that drying influences the ascorbic acid content in the dried peels. Heat treatment induces the degradation of ascorbic and affects negatively other quality parameters $[20,21]$.

\section{Conclusion}

The present research work gives interesting data about physiochemical and biochemical analysis of powder of prickly pear fruit peels. Through the reported results we can affirm that the dried peels of prickly pear fruit (powders) could constitute a promising source of natural dyes which may be exploited in food and cosmetic because of their richness in pigments (betacyanins, indicaxanthins, and carotenoids). The powder of prickly pear fruit peels also possesses a nutritional composition including sugar proteins, vitamins that make this powder interesting for human food.

\section{Data Availability}

The data used to support the findings of this study are included within the article.

\section{Conflicts of Interest}

The authors declare that there are no conflicts of interest.

\section{Acknowledgments}

The authors extend their appreciation to the Research Supporting Project (no. RSP2019/110), King Saud University, Riyadh, Saudi Arabia, for financial support.

\section{References}

[1] C. A. Shoemaker, "Plants and human culture," Journal of Home \& Consumer Horticulture, vol. 1, no. 2-3, pp. 3-7, 1994.

[2] V. C. Von Mark and D. A. Dierig, Industrial Crops: Breeding for Bioenergy and Bioproducts, Vol. 9, Springer, Berlin, Germany, 2014.

[3] A. Monjauze, H. N. Le Houérou, Le role des opuntias dans l'economie agricole de L'Afrique du Nord," Bull Ecole Sup Agron Tunis, vol. 1965, pp. 8-9, 1965.

[4] M. Arba, "Valorisation du figuier de barbarie en élevage," Bull Mens Inf Liaison PNTTA, vol. 68, pp. 1-4, 2000.

[5] A. Khales and M. Baaziz, "Etude des peroxydases d'écotypes d'Opuntia ficus indica L. en relation avec le développement dans les conditions de stress salin," in Proceedings of the Congrès International de Biochimie, Tokyo, Japan, May 2006.

[6] W. S. Harwood, New Creations in Plant Life: An Authoritative Account of the Life and Work of Luther Burbank, Macmillan, New York, NY, USA, 1921.

[7] O. Kabas, A. Ozmerzi, and I. Akinci, "Physical properties of cactus pear (Opuntia ficus India L.) grown wild in Turkey," Journal of Food Engineering, vol. 73, no. 2, pp. 198-202, 2006.

[8] J. C. B. Dubeux Jr., M. V. F. dos Santos, M. de Andrade Lira et al., "Productivity of opuntia ficus-indica (L.) miller under different $\mathrm{N}$ and $\mathrm{P}$ fertilization and plant population in northeast Brazil," Journal of Arid Environments, vol. 67, no. 3, pp. 357-372, 2006.
[9] F. Saidi, H. S. Cherif, H. Metidji et al., "Essais de multiplication in vitro par organogenese directe d'une plante medicinale aristolochia longa L," Agricultura, vol. 71, no. 3-4, 2009.

[10] P. Cunniff, Official Methods of Analysis of Aoac International: Food Composition, Additives, Natural Contaminants, AOAC International, Rockville, MA, USA, 1997.

[11] H. Alimi, N. Hfaeidh, Z. Bouoni, M. Sakly, and K. Ben Rhouma, "Protective effect of Opuntia ficus indica f. inermis prickly pear juice upon ethanol-induced damages in rat erythrocytes," Alcohol, vol. 46, no. 3, pp. 235-243, 2012.

[12] I. Hazbavi, M. H. Khoshtaghaza, A. Mostaan, and A. Banakar, "Effect of postharvest hot-water and heat treatmenton quality of date palm," Journal of the Saudi Society of Agricultural Sciences, vol. 14, no. 2, pp. 153-159, 2015.

[13] M. Sedki, A. Taoufiq, M. Haddouche, A. El Mousadik, M. Barkaoui, and E. El Mzouri, "Biophysical and biochemical characterization of cactus pear fruit (Opuntia spp.) cultivars originating from South-West Morocco," in Proceedings of the VII International Congress on Cactus Pear and Cochineal, vol. 995, pp. 83-91, Agadir, Morocco, October 2010.

[14] T. E. Moussa-Ayoub, S. K. El-Samahy, S. Rohn, and L. W. Kroh, "Flavonols, betacyanins content and antioxidant activity of cactus Opuntia macrorhiza fruits," Food Research International, vol. 44, no. 7, pp. 2169-2174, 2011.

[15] L. Ait Haddou, A. Blenzar, Z. Messaoudi, P. Van Damme, S. Boutkhil, and A. Et Boukdame, "Effet du cultivar, du prétraitement et de la technique de séchage sur quelques paramètres physico-chimiques des figues séchées de sept cultivars locaux du figuier (Ficus carica L.) au Maroc," European Journal of Scientific Research, vol. 121, no. 4, pp. 336-346, 2014.

[16] N. M'Hiri, "Étude comparative de l'effet des méthodes d'extraction sur les phénols et l'activité antioxydante des extraits des écorces de l'orange «maltaise demi sanguine» et exploration de l'effet inhibiteur de la corrosion de l'acier au carbone," Ph.D. thesis, Université de Lorraine, Nancy, France, 2015.

[17] N. M. El-Said, A. I. Nagib, Z. A. Rahman, and S. F. Deraz, "Prickly pear [opuntia ficus-indica (L.) Mill] peels: chemical composition, nutritional value, and protective effects on liver and kidney functions and cholesterol in rats," Functional Plant Science Biotechnology, vol. 5, no. 1, pp. 30-35, 2011.

[18] C. Sáenz and H. Berger, Utilización agroindustrial del nopal, Vol. 162, Food and Agriculture Organization, Rome, Italy, 2006.

[19] J. E. O'connell and P. F. Fox, "Proposed mechanism for the effect of polyphenols on the heat stability of milk," International Dairy Journal, vol. 9, no. 8, pp. 523-536, 1999.

[20] K. M. Clegg, "Non-enzymic browning of lemon juice," Journal of the Science of Food and Agriculture, vol. 15, no. 12, pp. 878-885, 1964.

[21] N. A. M. Eskin, "Biochemistry of food processing: browning reactions in foods," in Biochemistry of Foods, Vol. 2, Academic Press, Cambridge, MA, USA, 1990. 